\title{
ASSESSMENT OF FOLATE STATUS: MEASUREMENT OF HOMOCYSTEINE versus VITAMIN B12 AND FOLATE
}

\author{
Received 30/11/2002 - Accepted 30/06/2004
}

\begin{abstract}
There was no statistically significant difference between controls and patients for dietary folate. Also the plasma folate level did not slightly differ between the controls and patients. Patients had higher average homocysteine concentrations than control subjects $(p<0.05)$. A significant relationship was observed in controls between plasma folate concentrations and the homocysteine levels $(\mathrm{p}=0.01)$, and the folate questionnaire $(\mathrm{p}=0.001)$. We found in controls significant positive correlation between vitamin $\mathrm{B} 12$ and vitamin $\mathrm{B} 6(\mathrm{p}=0.05)$. In patients, vitamin $\mathrm{B} 12$ is inversely associated with homocysteine $(\mathrm{p}=0.05)$.
\end{abstract}

Keywords: Folic acid, vitamin B12, vitamin B6, homocysteine, folate status, food questionnaire of folate.

\section{Résumé}

La comparaison de la moyenne des valeurs de l'apport moyen journalier en folates dans le groupe témoin et le groupe des patients ne montre aucune différence significative. Egalement, la comparaison des valeurs en folates plasmatiques dans le groupe témoin et le groupe des patients, ne montre aucune différence significative. Les patients présentaient une homocystéinémie moyenne plus élevée que les sujets témoins $(\mathrm{p}<0,05)$. Il a été retrouvé chez les témoins une corrélation significative des folates plasmatiques avec, d'une part l'homocystéine et qui est inversement corrélée $(\mathrm{p}=0,001)$ et, d'autre part le questionnaire folate $(\mathrm{p}=0,001)$. Nous avons trouvé chez les témoins une corrélation positive entre la vitamine B12 et la vitamine B6 $(\mathrm{p}=0.05)$. Chez les patients, la vitamine $\mathrm{B} 12$ est inversement corrélé avec l'homocystéine $(\mathrm{p}=0.05)$.

Mots clés: acide folique, vitamine B12, vitamine B6, homocystéine, statut folate, questionnaire alimentaire folate.

\section{B. HOUCHER ${ }^{1}$ \\ D. NAIMI 2 \\ S. NECIB ${ }^{2}$ \\ M. CANDITO ${ }^{3}$ \\ S. BEGAG ${ }^{1}$}

${ }^{1}$ Laboratoire de Physiologie Cellulaire Département de Biologie

Faculté des Sciences

Université de Sétif

Sétif 19000, Algérie

${ }^{2}$ Laboratoire de Biologie-

Physiologie Cellulaire

Département de Biologie

Faculté des Sciences

Université Mentouri

Constantine, Algérie

${ }^{3}$ Laboratoire de Biochimie

Hôpital Pasteur

30 Avenue de la Voie Romaine

B.P. $69,06002-$-Nice Cedex 1, France

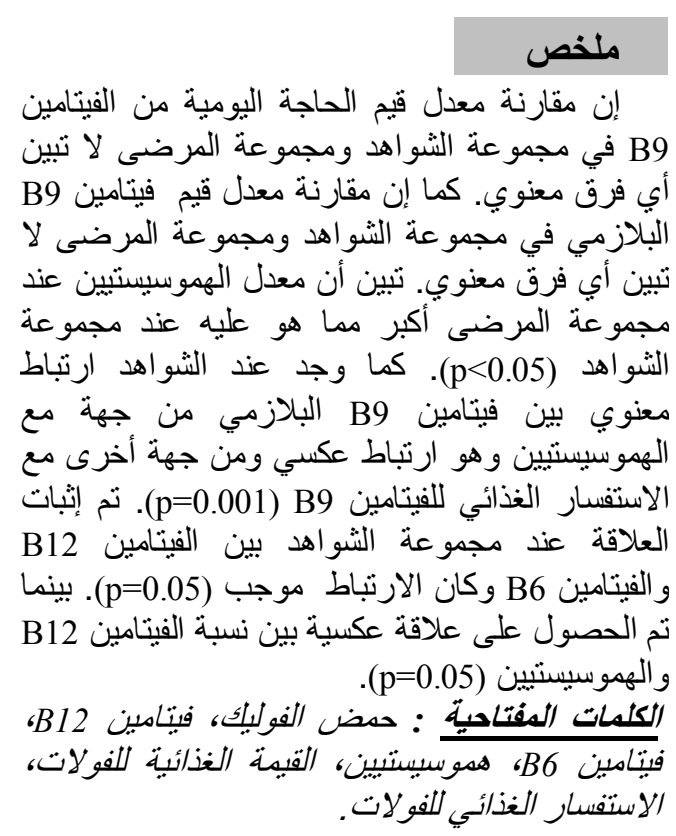

$\mathrm{M}$ alnutrition of folate and vitamin B12 (cobalamin) occurs on a world-wide scale. In Western societies about $10 \%$ have an inadequate intake. Higher incidences exist among females, the elderly and institutionalized [1]. Boiled extracts of certain food stuffs including vegetables, tomatoes and orange juice inhibit conjugase activity in vitro. Perhaps only half of the total folate in some diets is absorbable. Moreover cooking in large volumes of fluid destroys the folate in both green vegetables and meat. Heating also destroys vitamin B12, though it helps liberation from protein binders.

The average adult male needs about $200 \mu \mathrm{g}$ folate and the female about $170 \mu \mathrm{g}$ daily [1,2], however, Poitier de Courcy [3] recommended for men and women 330 and $276 \mu \mathrm{g} / \mathrm{d}$, respectively. A daily intake of 1 $\mu \mathrm{g}$ vitamin B12 is considered sufficient for adult [1], but the vitamin B12 RDA for adults is set at $2.0 \mu \mathrm{g}$ [2]. Very large doses of folic acid (100 or more times the RDA) may precipitate convulsions in persons whose epilepsy is in continuous control by phenytoin [4]. In laboratory animals, very large doses of folic acid given parenterally may precipitate in the kidneys, producing kidney damage and hypertrophy [4]. However, no clear toxicity has been reported from daily oral ingestion of up to $100 \mu \mathrm{g}$ of vitamin B12 [2]. Similarly, no benefit has been reported in non deficient people from such large quantities [2].

The factors responsible for deficiencies of folic acid and vitamin B12 are thought to include insufficient consumption of green vegetables and breakfast cereals, malabsorption due to atrophic gastritis, use of therapeutic agents and alcohol consumption [1]. Dietary deficiency of 
vitamin B12 is rare; more than $95 \%$ of the vitamin B12 deficiency is due to inadequate absorption [5].

A number of dietary and status index correlates or determinants of homocysteine have been identified, the most powerful and robust of which include the B-vitamins: folate, vitamin B12 and vitamin B6, whose metabolic functions are intimately connected with the metabolic pathways of homocysteine disposition [6].

In the healthy population with "normal" homocysteine levels and vitamin status currently regarded as adequate, folate seems to play the most important role in determining the blood homocysteine level [6]. Plasma homocysteine, a marker of cobalamin/folate status, is frequently increase in psychiogeriatric patients [7]. However, others have show that vitamin B6 deficiency does not necessary result in elevated homocysteine levels and thus is not a good indicator of vitamin B6 status [7].

The measurement of nutrient intake in large survey samples is a methodological challenge [8]. One challenge facing nutritional epidemiology is to measure long-term intake of nutrients accurately, including vitamins and minerals. Biologic measurements are valuable and are one of the methods used to validate diet information obtained using food frequency questionnaires (FFQ) [9].

The present study focuses on the evaluation of vitamin B12, folate, vitamin B6 and homocysteine biological status, and their changes with folate in healthy and hospitalised subjects. Also, we studied associations between plasma homocysteine and the vitamins.

\section{SUBJECTS AND METHODS}

\section{Subjects}

Sixty three (22 control; 41 hospitalised) subjects, aged $50 \pm 9$ participated in this study. The 41 patients, 4 women and 37 men, from department of Cardiology had suffered coronary heart disease, with clinical evidence of angian or myocardial infraction, plus 2 -fold or more rise in cardiac enzymes and angiographic evidence of $\geq 70 \%$ stenosis of a major coronary artery. The 22 healthy controls, 15 women and 7 men, were recruited among technicians in the laboratory. Short subjective questionnaires were answered by subjects, concerning their health, use of vitamin supplementation and medication.

\section{Dietary intake}

Dietary intakes of nutrients including folate were estimated using food records for each subject. On these dietary questionnaires, subjects reported their average intake of a specific portion size for these foods. These foods items were selected from a validated questionnaire used by "G. Poitier de Courcy". For each food item on the questionnaire, one response regarding frequency of intake is possible. The response individual food items were converted to average daily intake of folate for each participant. The average daily intakes of individual folate items were summed to compute the total folate intake.

\section{Biochemical analysis}

Fasting blood samples were collected from the anticubital vein of subjects using EDTA-treated vials.
Separated red blood cells (r.b.c.) were washed three or four times with saline solution. Separated plasma is stored at $20^{\circ} \mathrm{C}$, until analysis. Plasma vitamin B12 and plasma folate concentrations were estimated by microbiological assay using Lactobacillus leichmannii ATCC 7830 and Lactobacillus casei ATCC 7469, respectively. Plasma homocysteine concentration, was determined by fluorescence polarization immunoassay (FPIA) on an Imx apparatus (Abbott, Rungis, France). Pyridoxal phosphate (PLP), the active form of vitamin B6 was measured by HPLC-fluorescence (Recipe Kit, Precision Instrument, Marseille France).

\section{Statistical analysis}

Statistical analyses of vitamins and homocysteine were characterized by means and standard errors. Comparisons of mean differences were calculated by student's $t$-test and correlations between dietary and biochemical data were determined using Spearman rank correlation coefficients (statistica Software for Windows Version 5.1).

\section{RESULTS}

The mean age of control subjects was $48 \pm 9$ years (range, 26 to 59), and patients subjects was $52 \pm 9$ years (range, 30 to 66). The estimated mean daily intakes of folate, calculated from the dietary record data are presented in Table 1. The mean calculated daily intake of folate is above the questionnaire of "G. Poitier de Courcy". The percentage of nutrient intake for folate $(\mu \mathrm{g} / \mathrm{d})$ of the DRVs for folate in U.K. [10] is indicated in Table 1.

Table 1: Mean \pm s.d. estimated daily intakes for folate, and percentage of subjects at risk of vitamin deficiencies.

\begin{tabular}{|l|c|c|c|c|}
\hline \multicolumn{5}{|c|}{ Dietary intake } \\
\hline & $\begin{array}{c}\text { Folate } \\
(\mu \mathrm{g} / \mathrm{d})\end{array}$ & $<\mathrm{RNI}$ & $<\mathrm{EAR}(67 \% \mathrm{RNI})$ & $<\mathrm{LRNI}$ \\
\hline Controls & $186 \pm 77$ & 59 & 32 & 9 \\
\hline Patients & $178 \pm 67$ & 66 & 34 & 5 \\
\hline
\end{tabular}

DRVs for folate in U..K: Reference Nutrient Intake $(R N I)=200$ $\mu \mathrm{g}$, Estimated Average Requirement $(E A R)=140 \mu \mathrm{g}$, Lower Reference Nutrient Intake (LRNI) $=85 \mu \mathrm{g}(10)$.

Dietary levels of folate were slightly lower in patients than in controls (not significant), also the percentage of subjects at risk of vitamin deficiencies did not differ between groups (Tab. 1).

Mean plasma folate concentration in patients was lower than in controls $(6.68 \pm 2.52$ vs. $5.62 \pm 4.16 \mathrm{ng} / \mathrm{ml})$, however the difference was not significant. Even though 3 of $22(13.6 \%)$ control subjects had low plasma folate concentrations $(<4 \mathrm{ng} / \mathrm{ml})$, their folate status seemed to be normal as indicated by their corresponding tHcy concentrations and Q.folate.

Vitamin B6 concentrations in patients $(79 \pm 116 \mathrm{nmol} / \mathrm{l})$ were higher than in controls $(49 \pm 31 \mathrm{nmol} / \mathrm{l}, \mathrm{p}<0.05)$, vitamin B12 values did not differ between groups (355 \pm $162 \mathrm{pg} / \mathrm{ml}$ vs. $412 \pm 218 \mathrm{pg} / \mathrm{ml})$. Three patient subjects had plasma concentrations indicative of a suboptimal vitamin 
B12 status $(<150 \mathrm{pg} / \mathrm{ml})$.

Average homocysteine concentrations of controls and patients subjects did not differ between the groups (Table 2); eight patients (19.5\%) and two controls (9.5\%), respectively, had high plasma homocysteine concentrations $(>14$ $\mu \mathrm{mol} / \mathrm{l})$.

Table 2: Mean \pm s.d. of serum folates, vitamin B12, vitamin B6, and plasma homcysteine for controls $(\mathrm{n}=22)$ and patients $(\mathrm{n}=41)$.

\begin{tabular}{|l|c|c|c|c|}
\hline & $\begin{array}{c}\text { folate } \\
(\mathrm{ng} / \mathrm{ml})\end{array}$ & $\begin{array}{c}\mathrm{B} 12 \\
(\mathrm{pg} / \mathrm{ml})\end{array}$ & $\begin{array}{c}\mathrm{B} 6 \\
(\mathrm{nmol} / \mathrm{L})\end{array}$ & $\begin{array}{c}\text { Homocysteine } \\
(\mu \mathrm{mol} / \mathrm{L})\end{array}$ \\
\hline Controls & $6.68 \pm 2.52$ & $355 \pm 162$ & $49 \pm 31^{*}$ & $9.07 \pm 3.08^{*}$ \\
\hline Patients & $5.62 \pm 4.16$ & $412 \pm 218$ & $79 \pm 116$ & $12.93 \pm 8.79$ \\
\hline
\end{tabular}

$* P<0.05$ (for patients vs. controls).

A strong positive association was observed between plasma folate and Q.folate ( $\mathrm{rs}=0.697, \mathrm{p}<0.001)$ (Fig. 1). Homocysteine concentrations in plasma correlated inversely with concentrations of folate in plasma $(\mathrm{rs}=-0.538, \mathrm{p}<0.01)$ (Fig. 2), but not with vitamin B6, and vitamin B12 (rs = 0.038 , and $\mathrm{rs}=-0.075$, both not significant) (Tab. 3). Plasma vitamin B12 levels correlated with plasma vitamin B6 levels (rs $=0.475, \mathrm{p}<0.05)$.

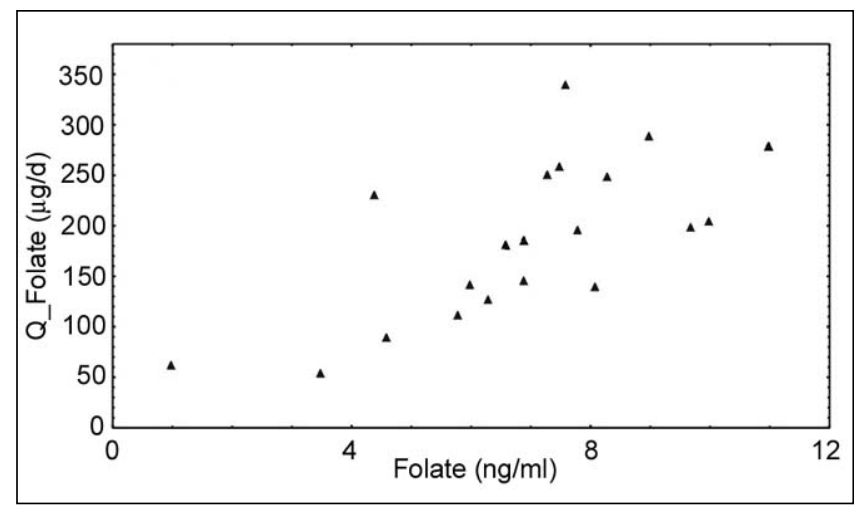

Figure 1: Correlation between questionnaire folate (Q.folate) and serum folate concentrations in controls (Spearman's rank correlation coefficient $r s=0.697, p<0.001$ ) .

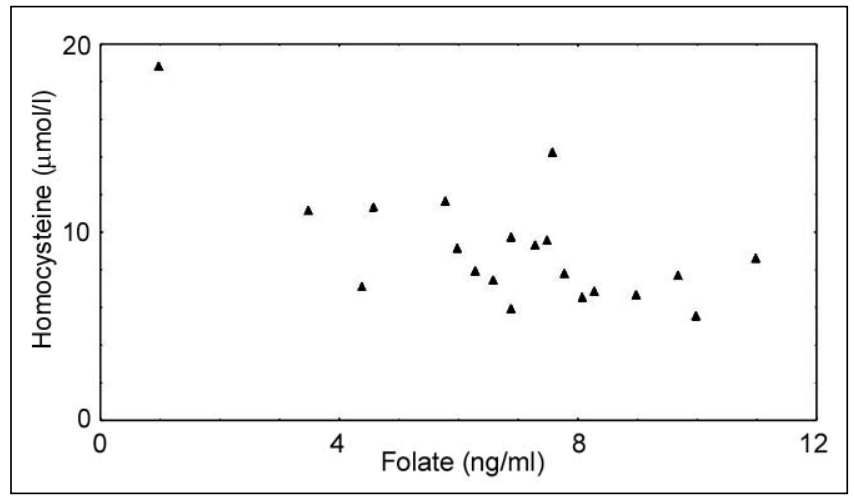

Figure 2: Correlation between serum homocysteine and serum folate concentrations in controls (Spearman's rank correlation coefficient $\mathrm{rs}=-0.538, \mathrm{p}<0.01$ ).

In the patient group, homocysteine is most strongly correlated with vitamin B12 as it was the case also in our patients ( $\mathrm{rs}=-0.333, \mathrm{p}<0.05)$. Q.folate was not related to both plasma homocysteine and folate concentrations.

Table 3: Spearman's rank correlation coefficients ( $p$ value), between plasma homocysteine, folate, vitamin B12, vitamin B6 and folate questionnaire (Q.folate) in 22 controls

\begin{tabular}{|l|c|c|c|c|}
\hline & B12 & B6 & Homocysteine & Q.folate \\
\hline Folate & -0.038 & -0.097 & $\mathbf{- 0 . 5 3 8 * *}$ & $\mathbf{0 . 6 9 7}$ \\
\hline Vitamin B12 & & $\mathbf{0 . 4 7 5 * * *}$ & -0.075 & 0.137 \\
\hline Vitamin B6 & & & 0.038 & 0.069 \\
\hline Homocysteine & & & & -0.268 \\
\hline
\end{tabular}

${ }^{*} p<0.001,{ }^{* *} p<0.01,{ }^{* * *} p<0.05$.

\section{DISCUSSION}

The folate status appears to be a greater concern than the vitamin B12 status for the elderly population. It seems that although mean values of dietary intake and plasma concentrations of folate may indicate nutritional adequacy, a proportion of older population may still bear nutritional risk [11].

Few studies have been done to assess folate intake in populations. The total folate intake in our population, is low (186 and 178 micrograms in control and patient subjects, respectively) compared to national averages for persons over 40 years (287 micrograms/day in NHANES I) [12]. Breakfast cereal fortification with folic acid at a level of $127 \mu \mathrm{g} / \mathrm{d}$ had a small effect (decrease of 3.7\%) on plasma homocysteine levels, but levels of $499 \mu \mathrm{g} / \mathrm{d}$ and $665 \mu \mathrm{g} / \mathrm{d}$ reduced homocysteine levels significantly, by $11 \%$ and $14 \%$ respectively [13].

The intake of folates as assessed by the Q.folate was correlated to serum folate levels $(\mathrm{rs}=0.697, \mathrm{p}<0.001$ ), which is similar to data reported by Jacques et al. [14]. However, others did not find any association between dietary intakes of the vitamins and their plasma or r.b.c. levels [11]. There is a clear relationship between homocysteine level and both folate intake and plasma folate concentration [15]. In our study, eight patients (19.5\%) had high plasma homocysteine concentrations $(>14 \mu \mathrm{mol} / \mathrm{L})$. However, in the patients that developed cardiovascular accidents, $83 \%$ had a homocysteine concentration of $>14$ $\mu \mathrm{mol} / 1[16]$.

In control subjects, only for folate (plasma and dietary levels of folate) did the association with homocysteine remain, whereas for vitamin $\mathrm{B} 6$ and $\mathrm{B} 12$, associations disappeared. Our results, have shown in control subjects an inverse correlation between plasma folate levels and homocysteine levels $(\mathrm{rs}=-0.538$ ), but not showed, a significant association between homocysteine and the level of serum vitamin B12 (as in other studies, [17]). Then, deficiency of folate, but not vitamin B12, can cause increased homocysteine concentration. Other studies have found that homocysteine is most strongly correlated with vitamin $\mathrm{B} 12$ as our results in the patient subjects ( $\mathrm{rs}=-$ 0.333). Nutritional studies have shown an inverse correlation between homocysteine and plasma concentrations both of vitamin B12 and folate [18,19], and it has demonstrated a progressive increase in plasma 
homocysteine with age, and strong inverse relationships with blood indices of folate, vitamin B12 and vitamin B6 status [20]. It is interesting to note that there was no difference between blood and questionnaire folate in patients and in controls. Moreover, blood and questionnaire folate correlated strongly within controls, but not such correlation existed in patients. The data seem to support the concept that in patients an increased degradation of folate may take place, probably due to oxidation [21]. It may result in an increased demand for folate in this group.

Pyridoxine does not appear to lower homocysteine levels significantly in most individuals [22], although in combination with folate there is some additional effect [23], and suggestive evidence, are protective factors [24].

The poor correlation between serum vitamin B12 level and homocysteine suggests that red cell folate (RCF) is a better measure of cellular cobalamin deficiency than serum vitamin B12 [25,26]. Our population with a low serum vitamin B12 or serum folate concentration are apparently not deficient in these vitamin. Serum folate is influenced by recent folate intake, whereas $\mathrm{RBC}$ folate more accurately reflects hepatic stores [27].

The amount of supplement in the dietary folate of $\sim 100$ $\mu \mathrm{g}$ per person per day, the mean serum folate concentration increased from 4.6 to $10.0 \mathrm{ng} / \mathrm{ml}$, whereas the mean homocysteine concentration decreased from 10.1 to 9.4 $\mu \mathrm{mol} / \mathrm{L}[28]$.

In addition, folate and vitamin B12 deficiency and the compensatory increase in homocysteine are a significant risk factor for cardiovascular disease [29]. Although no direct relationship could be demonstrated between any single vitamin and the degree of hyperhomocysteinemia, Ubbink et al. [30] suggest that all three vitamins may be interdependent determinants of circulating homocysteine concentrations.

Due to the important role of folate status as a determinant of homocysteine concentration, it may be necessary to redefine an adequate blood folate level and probably reformulate dietary allowances for this B-vitamin [6]. Thus, hyperhomocyteinemia it would still have to be determined, as the indicator, of the correction of the low functional vitamin status [31].

\section{CONCLUSION}

Homocysteine is a valuable functional index of micronutrient status and intakes for people, which can assist the development of the public health of the adult population. In our population, folate was the most important determinant of plasma homocysteine, even in subjects with apparently adequate nutritional status of this vitamin.

\section{REFERENCES}

[1]- Dawson D.W., Waters H.M., "Malnutrition: Folate and cobalamin deficiency", Br. J. Biomed. Sc., 51, (1994), pp.221-227.

[2]- National Research Council. Recommended Dietary Allowances, $10^{\text {th }}$ ed. Washington, D.C., National Academy Press, (1989), pp. 158-165.
[3]- Poitier de Courcy G., "Apports nutritionnels conseillés en folates", An. Biol. Clin., 59, (2001), pp.198-209.

[4]- Colman N., Herbert V., "Dietary assessments with special emphasis on prevention of folate deficiency", In: M. I. Botez and E.H. Reynolds, eds. Folic acid in Neurology, Psychiatry, and Internal Medicine. Raven press, New York, (1979), pp. 23-33.

[5]- Herbert V., "Vitamin B12", In: Nutrition Reviews, Present Knowledge in Nutrition, $5^{\text {th }}$ ed. The Nutrition Foundation, Washington, D.C., (1984), pp. 347-364.

[6]- Pietrzik K., Bronstrup A., "Vitamins B12, B6 and folate as determinants of homocysteine concentration in the healthy population", Eur. J. Pediatr., 157, (1998), pp. S135-S138.

[7]- Hultberg B., Isaksson A., Nilsson K., Gustafson L., "Markers for the functional availability of cobalamin/folate and their association with neuropsychiatric symptoms in the elderly", Int. J. Geriatr. Psychiatry, 16, (2001), pp. 873-878.

[8]- Brunner E., Stallone D., Juneja M., Bingham S., Marmot M., "Dietary assessment in Whitehall II: comparison of $7 \mathrm{~d}$ diet diary and food-frequency questionnaire and validity against biomarkers", Br. J. Nutr., 86, (2001), pp. 405-414.

[9]- Knutsen S.F., Fraser G.E., Linsted K.D., Beeson W.L., Shavlik D.J., "Comparing biological measurements of vitamin $\mathrm{C}$, folate, alpha-tocopherol and carotene with 24hour dietary recall information in nonhispanic blacks and whites", Ann. Epidemiol., 11, (2001), pp. 406-416.

[10]-Department of health. Folic Acid and the Prevention of Disease. Report on Health and Social Subjects, 50. London: HMSO, (2000).

[11]-Quinn K., Basu T.K., "Folate and vitamin B12 status of the elderly", Eur. J. Clin. Nutri., 50, (1996), pp.340-342.

[12]-Alaimo K., Mc Dowell M.A., Briefel R.R. et al., "Dietary Intake of Vitamins, Minerals, and Fiber of Persons Ages 2 Months and Over in the United States: Third National Health and Nutrition Survey, Phase 1, 1988-91", National Center for Health Statistics. Advance Data No 258, (1994).

[13]-Malinow M.R., Duell P.B., Hess D.L., Anderson P.H., Kruger W.D., Phillipson B.E., Gluckman R.A., Block P.C., Upson B.M., "Reduction of plasma homocyst(e)ine levels by breakfast cereal fortified with folic acid in patients with coronary heart disease", New Engl. J. Med., 338, (1998), pp. 1009-1015.

[14]- Jacques P.F., Sulsky S.I., Sadowski J.A., Phillips J.C., Rush D., Willett W.C., "Comparison of micronutrient intake measured by a dietary questionnaire and Biochemical indicators of micronutrient status", Am. J. Clin. Nutr., 57, (1993), pp. 182-189.

[15]-Selhub J., Jacques P.F., Wilson P.W., Rush D., Rosenberg I.H., "Vitamin status and intake as primary determinants of homocysteinemia in an elderly population", JAMA, 270, (1993), pp. 2693-2694.

[16]-van Guldener C., Robinson K., "Homocysteine and renal disease", Seminars in Thrombosis and Hemostasis, 26, (2000), pp. 313-324.

[17]-Hughes K., Ong C.N., "Homocysteine, folate, vitamin B12, and cardiovascular risk in Indians, Malays, and Chinese in Singapore", J. Epidemiol. Community Health, 54, (2000), pp. 31-34.

[18]-Brattstrom L.E., "Vitamins as homocysteine lowering agents", J. Nutr., 126, (1996), pp. 1276S-1280S.

[19]-Marasini B., Casari S., Bestetti A., Maioli C., Cugno M., Zeni S., Turri O., Guagnellini E., Biondi M.L., "Homocysteine concentration in primary and systemic sclerosis associated Raynaud's phenomenon", J. Rheumatol., 27, (2000), pp. 2621-2623.

[20]-Bates C.J., Mansoor M.A., Gregory J., Pentieva K., Prentice A., "Correlates of plasma homocysteine, cysteine and 
cysteinyl-glycine in respondents in the British National Diet and Nutrition Survey of Young People Aged 4 -18 Years, and a comparison with the Survey of People Aged 65 Years and Over, Br. J. Nutr., 87, (2002), pp. 71-79.

[21]- Fuchs D., Jaeger M., Widner B., Wirleitner B., Artner-Dworzak E., Leblhuber F., "Is hyperhomocysteinemia due to the oxidative depletion of folate rather than to insufficient dietary intake?", Clin. Chem. Lab. Med., 39, (2001), pp. 691-694.

[22]- Verhoef P., Stampfer M.J., Buring J.E., Gaziano J.M., Allen R.H., Stabler S., Reynolds R.D., Kok F.J., Hennekens C.H., Willett W.C., "Homocysteine metabolism and risk of myocardial infarction: Relation with vitamins B6, B12, and folate", Am. J. Epidemiol., 143, (1996), pp. 845-859.

[23]-Kruger W.D., "Vitamins and homocysteine metabolism", Vitamins and Hormones, 60, (2001), pp. 333-352.

[24]-Robinson K., Arheart K., Refsum H., Brattstrm L., Boers G., Ueland P., Rubba P., Palma-Reis R., Meleady R., Daly L., Witteman J., Graham I., "The European Comac Group. Low circulating folate and vitamin B6 concentrations: risk factors for stroke, peripheral vascular disease, and coronary artery disease", Circulation, 97, (1998), pp. 437-443

[25]-Curtis D., Sparrow R., Brennan L., van der Weyden M., "Elevated serum homocysteine as a predictor for vitamin
B12 or folate deficiency", Eur. J. Haematol., 52, (1994), pp. 227-232.

[26]-Compher C.W., Kinosian B.P., Evans-Stoner N., Huzinec J., Buzby G.P., "Hyperhomocysteinemia is associated with venous thrombosis in patients with short Bowel syndrome", Journal of Parenteral and Enteral Nutrition, 25, (2001), pp. 1-8.

[27]-Snow C.F., "Laboratory diagnosis of vitamin B12 and folate deficiency", Arch. Inter. Med., 159, (1999), pp. 1289-1298.

[28]-Jacques P.F., Selhub J., Bostom A.G., Wilson P.W.F., Rosenberg I.H., "The effect of folic acid fortification on plasma folate and total homocysteine concentrations", $N$. Engl. J. Med., 340, (1999), pp. 1449-1454.

[29]-Klee G.G., "Cobalamin and folate evaluation: Measurement of methylmalonic and homocysteine vs vitamin B12 and folate", Clin. Chem., 46, (2000), pp. 1277-1283.

[30]-Ubbink J.B., Vermaak W.J.H., van der Merwe A., Becker P.J., "Vitamin B-12, vitamin B-6, and folate nutritional status in men with hyperhomocysteinemia", Am. J. Clin. Nutr., 57, (1993), pp. 47-53.

[31]- van Guldener C., Stehouwer C.D.A., "Hyperhomocysteinemia, vascular pathology, and endothelial dysfunction", Seminars in Thrombosis and Hemostasis, 26, (2000), pp. 281-289. 